\title{
Implementation of Fraud Risk Assessment To Mitigate The Fraud Risk in Tax Audit Process
}

\author{
Qomarudin Alfatah ${ }^{1 *}$ and Nicholas Agustinus L. Tobing ${ }^{2}$ \\ 1,2 Universitas Indonesia, Depok, Indonesia
}

\begin{abstract}
The emergence of a variety of fraud schemes, ineffective internal controls, and the number of fraud cases that occur in the taxation sector, encourage researches related to fraud risk assessment, especially in tax audit activities. This study aimed to identify potential fraud schemes risks, evaluate risk controls and discuss anti-fraud strategies using a case study at the Directorate General of Taxes in Indonesia. With a sequential mix method approach through a combination of quantitative and qualitative research, and by using rational choice theory, this research extends the literature of previous studies by providing evidence that fraud can be prevented by increasing the probability to detect fraud scheme. This study fills out the gaps related to fraud risk assessment research in the tax audit process which have been rarely performed in the literatures.

The results concluded that of the 20 fraud scenarios identified, there were 7 fraud scenarios categorized as high level of residual fraud risk, 9 fraud scenarios at the medium level, and the rest at low levels. This study discussed appropriate controls to mitigate the residual fraud risk to be maintained at the level of organizational risk appetite. In addition, this study also discussed anti fraud strategies that are relevant to the organization, through evaluating anti-fraud strategies that have been previously implemented and anti-fraud strategies that have never been implemented.
\end{abstract}

Keywords: Anti-Fraud Program, Fraud, Fraud Risk Assessment, Tax Audit

\section{Introduction}

Tax reform at the Directorate General of Taxes (DGT) was carried out as a manifestation of good governance implemented through reform in the field of taxation policy and tax administration. This reform aimed to lead good and corruption-free organization to achieve optimal state revenues. Optimal tax revenue will increase the credibility of state budget, so that the function of stabilization, allocation and budget redistribution becomes optimal. Data on the realization of tax revenues from 2014 to 2018 has increased along with the increase in GDP. However, in terms of the target performance ratio and tax ratio, the value has decreased (DJP, 2017). If the tax ratio is maintained at a more optimal level, the tax revenues will be higher.

In addition to external factors, internal factors also influence the decline in the value of the target performance ratio and tax ratio. Internal factors are related to how the policy formulation process is carried out, implemented, and reviewed. In these processes, the implementation of internal audits plays an important role because it provides adequate confidence that functions and activities are performed effectively and efficiently and the main risks of the organization are well identified and managed (IIA, 2009).

In an effort to increase the tax ratio, the problem arises when fraud behavior affecting the tax ratio (Ghura, 1998). In line with this, inefficiencies and corruption also affect the tax ratio (Rizal, 2011). Based on the initial interviews, there were problems that the handling of fraud at the DGT had not been optimally carried out. Organization has not implemented fraud risk assessment spesifically in implementing anti-fraud strategies. Fraud risk assessment is needed to help focus the management's attention on significant fraud risks that must be addressed (Bell, 2010), so that it will increase the success of the anti-fraud strategy (KPMG Forensics, 2014).

* Corresponding author. Email address : qomarudinalfatah@gmail.com 
Fraud schemes can occur in various business processes of the DGT's main activities, including tax audits (DJP, 2016). These main business processes were chosen as the research object because they pose high inherent risks, significant transaction volume, activity characteristics, and the high number of disciplinary sentences (Table $1)$.

Table 1 Violation and Discipline Punishment

\begin{tabular}{|c|c|c|c|c|}
\hline $\begin{array}{l}\text { Description } \\
\text { Number of complaints }\end{array}$ & $\begin{array}{l}2015 \\
186\end{array}$ & $\begin{array}{l}\mathbf{2 0 1 6} \\
190\end{array}$ & $\begin{array}{l}\mathbf{2 0 1 7} \\
223\end{array}$ & $\begin{array}{l}2018 \\
191\end{array}$ \\
\hline \multicolumn{5}{|l|}{ Types of Violations } \\
\hline $\begin{array}{l}\text { Request or receive money } \\
\text { /goods/facilities }\end{array}$ & 50 & 41 & 25 & 41 \\
\hline Abuse of electronic data usage & 2 & 0 & 1 & 1 \\
\hline Office financial misuse & 12 & 8 & 6 & 8 \\
\hline Official violation & 24 & 22 & 46 & 36 \\
\hline Misuse in procurement & 0 & 2 & 0 & 1 \\
\hline $\begin{array}{l}\text { Violation of employee honor and } \\
\text { dignity }\end{array}$ & 0 & 22 & 17 & 31 \\
\hline Others & 78 & 69 & 105 & 73 \\
\hline Disciplinary punishment & 78 & 93 & 122 & 111 \\
\hline
\end{tabular}

The number of complaints of violations at DGT tends to increase and the types of violations including requesting/receiving money/goods/facilities contribute as a large proportion. In every fraud act carried out by fraud perpetrators, the Fraud Triangle Theory explained three key factors as triggers namely pressure, opportunity, and rationalization (Cressey, 1953). To minimize fraud behavior, Rational Choice Theory (Becker, 1974), predicts that fraud can be prevented by increasing the probability/possibility to detect fraud. The application of good internal controls such as using a whistleblowing system (WBS), code of ethics and the effective implementation of internal audits should reduce the potential to commit fraud.

In a risk-based internal audit framework, all risks associated with achieving organizational goals, including risk of fraud, are analyzed to be mapped to determine audit priorities based on the most priority risks. This study introduces the application of Fraud Risk Assessment at DGT that will assist the organization in identifying the risks of fraud. The results of fraud risk assessment allow the better and relevant design and implementation of anti fraud strategies for the organization in eliminating residual fraud risk to the level of organizational risk appetite.

\subsection{Research Questions and Research Objectives}

Based on the background described, this study aimed to answer three research questions including,

1) What fraud schemes might occur in tax audit activities at the DGT?

2) How should the fraud risk assessment be implemented on tax audit activities?

3) How were the relevant anti-fraud programs to mitigate the fraud risk?

The purpose of this study was to discuss the identification of schemes/fraud scenarios that may occur in the business process cycle, analyze the implementation of the fraud risk assessment and evaluate the implementation of anti-fraud programs implemented and discuss anti-fraud programs that are appropriate and relevant for the organization based on the fraud risk assessment conducted.

\subsection{Research Contribution}

Ellet (2009) explains that there are four contributions of research from the results of the expected case studies, namely evaluation, problem solving, decision making, and rule determinations. In addition, the expected results in the case study can be 
suggestion for research objects and action plans including the possible risks faced and suggestions on how to mitigate them (Wasistha, Yuniasih, \& Shauki, 2018).

This study contributed to the evaluation and problem solving in the area of fraud risk management, specifically for the DGT. Evaluation was carried out on fraud handling processes that have been implemented by the organization. Problem solving related to discussions on how to handle fraud that is relevant for the organization, through anti-fraud programs that have been formulated based on fraud risk assessment.

This study filled out the research gap related to fraud risk assessment in tax audits activities which have been rarely performed by previous studies. This study also answered Alfurqan (2017), related to the suggested research to identify fraud risks in other business processes and design the internal audit division structure. In addition, this study was expected to contribute as a reference of literature study on the implementation of fraud risk assessment in tax sector government agencies and as reference to future studies.

\section{Literature Study}

\subsection{Fraud Triangle Theory}

The Fraud Triangle Theory introduced by Donald Cressey, can be used in analyzing how fraud can occur so that it helps in the prevention and detection of fraud. Based on this theory, the occurrence of a fraud behavior is caused by three general factors, namely pressure, rationalization, and opportunity. Pressure is an incentive or need for fraud, which includes external pressure, personal financial needs, and financial targets. Rationalization is an attitude or set of ethical values that allow a person to commit fraud or rationalize fraud behavior. While opportunity is a situation that opens opportunities that enable the occurrence of fraud (Cressey, 1953).

One of the analyzes in this study argues that fraud behavior is possible, whether done by DGT employees or outside parties. Position and authority are real opportunities that can trigger fraud behavior to occur. The high set financial target or problematic personal financial condition is an example of financial pressure which also contributes to fraud. In addition, rationalization of the contribution of an employee to the organization can lead to potential fraud.

\subsection{Rational Choice Theory}

Rational Choice Theory predicts that fraud can be prevented by increasing the probability of fraud to be detected (Becker, 1974). Based on this theory, a person's decision to engage in criminal activities, such as fraud, requires a cost-benefit analysis. If an individual thinks that the expected benefit of a crime is less than the expected cost (that is, the sanction multiplied by its probability), then the rational individual will choose not to get involved in crime.

As one of the analyzes in this study is the argument that the application of WBS, code of ethics and good internal audit will increase the probability of detecting fraud, so that individuals will tend to not commit fraud. The application of the WBS and internal audit will prevent fraud from happening because the fraudster will think and consider the costs to be faced, including the probability of fraudulent actions being detected.

\subsection{Fraud Risk Assessment}

Fraud has various definitions. The definition of fraud according to the Black's Law Dictionary is:

.. a knowing misrepresentation of the truth or concealment of a material fact to induce another to act to his or her detriment. Fraud is usual a tort, but in some cases (esp. when the conduct is willful) it may be a crime (Nicke, 2003) 
Furthermore, ACFE divides the types of fraud into three types based on their actions (The Fraud Tree), namely Asset Misappropriation, Fraudulent Statement and Corruption (Padgett, 2015). One way to manage fraud problems is to know various fraud schemes for mitigation through effective control. Committee of Sponsoring Organizations of the Treadway Commission (COSO) describes this activity in a fraud risk assessment framework. Based on the definition, fraud risk assessment is:

.. a fraud risk assessment is a dynamic and iterative process for identifying and assessing fraud risks relevant to the organization (Cotton, Johnigan, \& Givarz, 2013).

This definition provides an understanding that the process of assessing a fraud risk is dynamic and repetitive. In addition, adjustments can be made according to the complexity and objectives of the organization. In conducting a risk assessment, one should consider the scheme/fraud scenarios that might occur in the organization to obtain an appropriate anti fraud guideline for the organization. As stated by COSO in Alfurqan (2017), illustrates the Fraud Risk Assessment as follows:

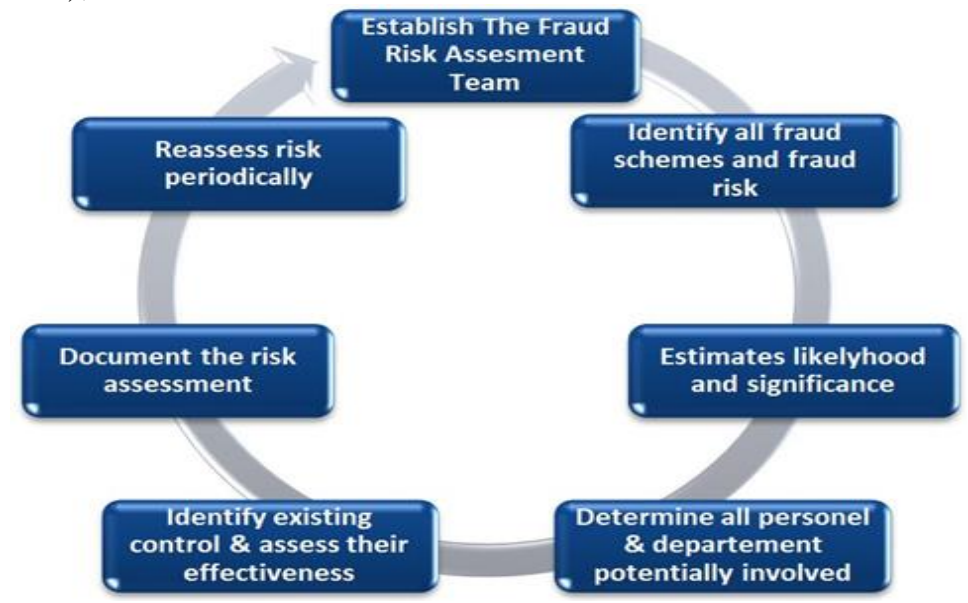

Figure 1 Fraud Risk Assessment Process

\subsection{Anti Fraud Strategy}

An effective anti fraud strategy should be based on the results of a fraud risk assessment. The anti fraud strategy may include preventive, detective or investigative strategies.

1) Preventive. Preventive anti-fraud strategies include fraud awareness, building code of conduct, training, and others.

2) Detective. The implementation of detective anti fraud strategies includes the implementation of WBS, Key Fraud Indicators, special audit procedures related to certain schemes, and others.

3) Investigative. Investigation is carried out through a procedure of relevant and sufficient data collections, which is intended to reject or support an allegation of fraud (Vona, 2008).

\subsection{Previous Study}

Research conducted by Alfurqan (2017) regarding the fraud risk assessment implemented in the procurement business process resulted in 23 identified fraud schemes that were useful in designing relevant anti fraud strategies. In other study, a fraud scheme integrated in the fraud risk assessment can help better audit planning (Gao, Srivastava, \& Mock, 2008). Regarding the analysis of the implementation of the anti fraud strategy, Widoretno (2016) proved that the role of internal audit in anti fraud strategies contributed to the realization of Good Corporate Government. A research in the banking sector showed that fraud risk management had a positive relationship with 
banking performance (Hussaini, 2018). In another study, the Fraud Risk Assessment can affect the auditor's evaluation of evidence and assessment (Rose \& Rose, 2003).

\subsection{Research Process}

Figure 2 describes the research framework used in this study.

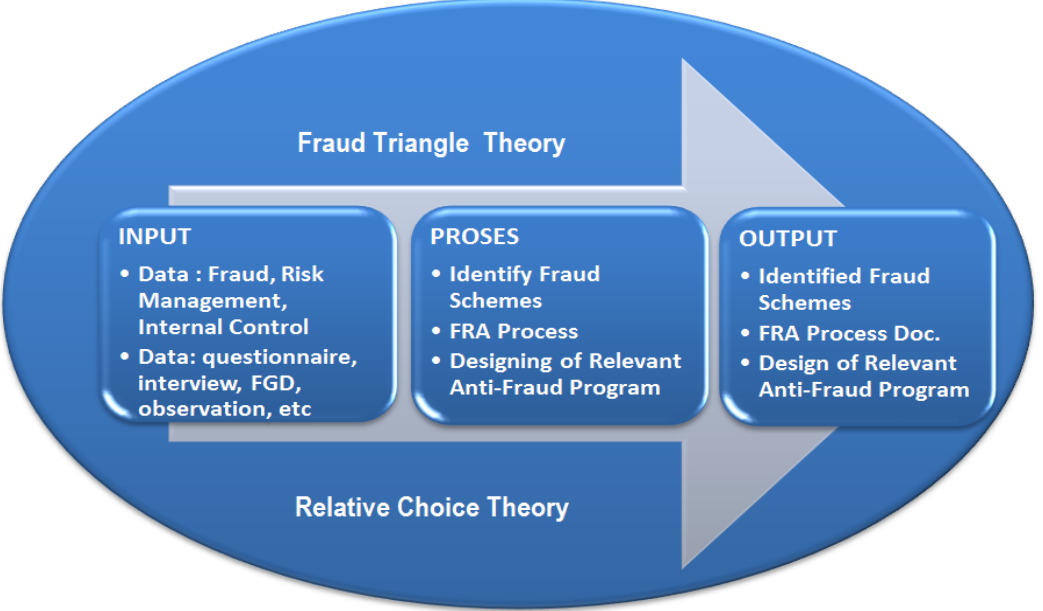

Figure 2 Research Process

\section{Research Methodology}

\subsection{Research Strategy and Approach}

This research uses a case study strategy. Case studies were carried out by exploring phenomena related to fraud risk in the scope of the business processes of the main activities at DGT. In case studies, research is conducted in a systematic and organized way to produce information about a topic and focus on certain limitation, events, or phenomena (Stake, 2000). In addition, this research approach uses a sequential mix method, combining quantitative and qualitative research approaches.

\subsection{Data Collection}

Data in this study were obtained from primary and secondary sources. Primary data were obtained from questionnaires (quantitative), interviews, observations, and focus group discussions (FGD), while for secondary data were obtained from documentation. The questionnaire in this study was used to complement and encourage the direction of the questions in the interview. The questionnaire material was adapted from the ACFE Fraud Risk Assessment Tool material module. The results from the questionnaire were then quantified according to the specific theme content as material for deepening the material in the subsequent research process such as interviews and observations. The number of respondents in the questionnaire is planned to be 300 respondents to represent around 30 units of DGT Regional Offices in Indonesia. In each DGT Regional Office, 10 tax office employees in Medium Tax Office and Small Tax Office within the geographical area of the DGT Regional Office, positioned as tax auditors, account representatives, and middle executives with a tenure of more than 10 years, are involved as respondents.

In conducting interviews, this study used semi structured in-depth interview techniques. In-depth interviews were considered to be richer in complex information, especially on respondent information that contains opinions, attitudes, experiences, and others. Interviews were planned at DGT Headquarters units, DGT Regional Offices, Medium Tax Office and Small Tax Office which were sampled by job criteria and work periods determined in the questionnaire. The observations were carried out by directly observing the activities that occurred on a business process or part of the activities of the object under study. It used multiple observation because the objects studied included the DGT Headquarters, Medium Tax Office and Small Tax Office. Focus 
group discussions were conducted to strengthen and validate the results of the interviews so that sufficient data conclusions were obtained.

\subsection{Data Analysis}

In analyzing the data, this study used content analysis and thematic analysis techniques. The primary data were obtained from the sample population of DGT employees including various positions such as staff, account representatives, tax auditors, internal auditors, investigators, chief executives, and others. This study used data validity techniques in the form of data validity for thruthworthiness. As stated by Krisyantono (2006) in Alfurqan (2017), the validity of thurthworthiness data was a test of the truth and honesty of the subject in expressing reality as with what happened/experienced. The answers of the research subjects were also analyzed and confirmed related to the validity of the data through the results of FGD and with other data sources.

This research was carried out by implementing a fraud risk assessment. Fraud risk assessment was performed by analyzing schemes and fraud scenarios that might occur in the organization, especially in the main business processes of the organization that have a high tendency of impact and level of occurrence. Furthermore, measurements were taken regarding the effectiveness of inherent controls so that residual risk was obtained for further handling. Designing and implementing an antifraud strategy that was sufficient and relevant for the organization would potentially eliminate all residual risk to the level of organizational risk appetite.

\subsection{Unit of Analysis}

This research was conducted at the Directorate General of Taxes (DGT), the Ministry of Finance of Indonesia which focused on one of the main business process activities, namely tax audits. Tax audit activities activities were chosen as the object of research after preliminary research on various business process activities at the DGT with consideration to the selection basis. The basis for the selection were high inherent risk, significant transaction volume, characteristics, and the number of disciplinary sentences.

Tax audit activities starts with the preparation of the tax audit plan and the tax audit program by the tax audit team, followed by borrowing documents/data from taxpayers. After tax return documents (SPT) are examined, the notification of the findings of the examination results is entitled to be responded to. The tax payable based on the final discussion on the results of the audit is then documented and becomes the basis for issuing tax assessment letters (Kementerian Keuangan, 2013).

\section{RESULTS}

\subsection{Result}

The main purpose of this research was to summarize and discuss the research findings from the four research instruments used (questionnaires, interviews, observations, and FGDs). The questionnaire was conducted during March 2019 while interviews, observations and FGDs were conducted during the period of April 2019. This study tried to answer three research questions including any fraud schemes that might occur in tax audit activities, how to implement fraud risk assessment on the activities and how to implement the relevant anti fraud program to mitigate the fraud risk.

\subsection{Research Finding}

The questionnaire in this study was designed to be distributed to 300 selected respondents. However, only 163 questionnaires were returned (54.33\% response rate) from 300 questionnaires that had been successfully distributed. Interviews and FGDs were conducted at the sampled DGT Headquarters, Medium Tax Offices and Small Tax Offices. Observations was only carried out at the Small Tax Offices. 


\section{Discussion}

The discussion in this section deals mainly with the topics in research questions.

\subsection{Identification of Fraud Schemes and Scenarios}

Fraud schemes and scenarios were collected from all research instruments used, historical information, and various other sources. By using content analysis and thematic analysis of the data that has been obtained, this study found 20 fraud schemes/scenarios that might occur in the tax audit business process, as listed in table 5 in the appendix. In the table, generally the fraud schemes that occur were bribery, conflicts of interest, gratuities, extortion, theft of cash, falsification of information/documents, misuse of information data, misuse of assets, kick back, management override, and others. These fraud schemes were very closely related to the theory used in this study as mentioned in the literature study. One example in this study is conflict of interest. Based on the fraud triangle theory, conflict of interest could occur because of an opportunity either from the tax auditor or from the taxpayer to commit fraud. In addition, based on rational choice theory, conflict of interest could occur because fraudsters understood that the fraud committed were likely not to be detected.

\subsection{Conducting Fraud Risk Assessment}

DGT already has a risk management policy, but related to the risk of fraud has not been specifically carried out mainly related to the establishment of a strong fraud risk assessment team and identification of specific fraud schemes/scenario. The results of the interview indicated that the handling of risk is actually not the core work in the office so that in pracatice it is handled by ordinary staff who may be less competent in identifying fraud schemes. In identifying the risk of fraud must be carried out by a competent team.

In conducting a fraud risk assessment, the fraud schemes and scenarios that have been identified in this research were then assessed for the level of the likelihood and significance. One of the factors that influence the likelihood assessment was the possibility of risks that occur based on historical information, while the significance (impact) assessment was based on financial losses and organizational reputation. In this case, the assessment of likelihood is also closely related to rational choice theory. The higher the chance of fraud comitted will not be detected, the higher assessment of likelihood, and vice versa. The results of these assessments are presented in the Inherent Vulnerability Level Matrict Table (tables 2), with detailed information presented in Table 5 in the Appendix. Table 2 showed 8 fraud schemes with high levels and 10 with medium levels (before control was applied). The numbers listed in the table below and also for the following table, refer to the sequence number of the fraud scheme listed in Tables 5 in the Appendix.

Table 2 Inherent Vulnerability Level Matric in Tax Audit

\begin{tabular}{|c|c|c|c|c|c|}
\hline \multirow{2}{*}{$\begin{array}{c}\text { SIGNIFICANCE } \\
\text { LEVEL }\end{array}$} & \multicolumn{5}{|c|}{ LIKELIHOOD LEVEL } \\
\hline & $\begin{array}{l}\text { IMPROBA } \\
\text { BLE }\end{array}$ & REMOTE & $\begin{array}{l}\text { OCCA } \\
\text { SIONAL }\end{array}$ & PROBABLE & $\begin{array}{c}\text { FRE } \\
\text { QUENT }\end{array}$ \\
\hline NEGLIGIBLE & Negligible & Negligible & Low & Low & Low \\
\hline MINOR & Negligible & Negligible & Low & Low & Low \\
\hline MODERATE & Low & Low & Low & $\operatorname{Mer}_{2,3,4,17}$ & High \\
\hline MAJOR & Low & Low & $N_{6,10,16,19,20}^{\alpha}$ & High $_{12,8,9}$ & High \\
\hline $\begin{array}{l}\text { CATASTRO } \\
\text { PHIC }\end{array}$ & Low & Mediun 5 & $\mathrm{Hi} \mathbf{7} \mathbf{1 3 , 1 5}$ & High & Higl 1,11 \\
\hline
\end{tabular}

The next step was to assess the residual risk vulnerability level, by evaluating the effectiveness of internal controls in each fraud scheme and evaluating potential residual risk. Residual risk was defined as the risk that remains after the implementation of internal control, which requires further handling. Based on rational choice theory, 
effective internal control can reduce the potential for fraud to be carried out because of effective detection. Rational Choice Theory predicts that fraud can be prevented by increasing the probability of fraud to be detected (Becker, 1974). The results of the residual risk assessment are presented in column (6) in Tables 5 in the Appendix ordered based on the handling priority. After assessing the residual risk vulnerability level, risk probability level (the level of possibility of fraud from residual risk) was determined. This calculation was done by collaborating the residual risk vulnerability level and likelihood. The risk probability level map are shown in Tables 3 (after control was applied).

Table 3 Risk Probability Level in Tax Audit

\begin{tabular}{|c|c|c|c|c|}
\hline \multirow{2}{*}{$\begin{array}{c}\text { LIKELYHOOD } \\
\text { LEVEL }\end{array}$} & \multicolumn{4}{|c|}{ RESIDUAL RISK LEVEL } \\
\hline & $\begin{array}{l}\text { NEGLIGI } \\
\text { BLE }\end{array}$ & LOW & MEDIUM & HIGH \\
\hline IMPROBABLE & Improbable & Improbable & Improbable & Improbable \\
\hline REMOTE & Improbable & Remo1 14,18 & Remote & Remote \\
\hline OCCASIONAL & Improbable & Remote 6,10 & $\mathbf{O}_{15,16,19,20}$ & Occasion 7,13 \\
\hline PROBABLE & Improbable & Occasiona 9 & Pre $2,3,4,8,17$ & Probable 12 \\
\hline FREQUENT & Improbable & Occasional & Probable & Frequent 1,11 \\
\hline
\end{tabular}

The final stage in fraud risk assessment was to assess the overall level of risk from residual risk (overall risk level of the residual risk), through a combination of risk probability level and impact, presented in Tables 4 . In the table, overall residual risk that must be addressed were those having high and medium level (according to DGT risk appetite), including 7 high level risks and 9 medium level risks. These results serve as guidelines for management to perform mitigation actions on each fraud risk.

Table 4 Overall Residual Risk Ranking in Tax Audit

\begin{tabular}{|c|c|c|c|c|c|}
\hline \multirow{2}{*}{$\begin{array}{c}\text { SEVERITY } \\
\text { LEVEL }\end{array}$} & \multicolumn{5}{|c|}{ PROBABILITY } \\
\hline & $\begin{array}{l}\text { IMPROBA } \\
\text { BLE }\end{array}$ & REMOTE & \begin{tabular}{|c|} 
OCCA \\
SIONAL
\end{tabular} & $\begin{array}{l}\text { PROBA } \\
\text { BLE }\end{array}$ & $\begin{array}{c}\text { FRE } \\
\text { QUENT }\end{array}$ \\
\hline NEGLIGIBLE & Negligible & Negligible & Low & Low & Low \\
\hline MINOR & Negligible & Negligible & Low & Low & Low \\
\hline MODERATE & Low & Low & Low & $\mathrm{Me}_{2,3,4,17}$ & High \\
\hline MAJOR & Low & Low $6,10,14$ & 19.16,19,20 & High 8,12 & High \\
\hline $\begin{array}{l}\text { CATASTRO } \\
\text { PHIC }\end{array}$ & Low & Medium 5 & $\mathbf{7 , 1 3 , 1 5}$ & High & Hig 1,11 \\
\hline
\end{tabular}

DGT determined to have risk appetite only in negligible and low level risks. Therefore, all risks that are in the medium and high level must be responded to and mitigated by avoiding, transferring, or reducing them.

Based on the results of interviews, management preferred to prioritize risk mitigation by reducing risk. This risk mitigation is to be done by increasing the internal control so that the risk level is reduced to the area of risk appetite. This option was seen as more rational because of the consideration of cost efficiency, effectiveness and timeliness. In line with this, this study discusses the issue of overall residual fraud risk that must be addressed immediately, which includes 7 high-level fraud risks and 9 medium-level fraud risks. A summary of the discussion regarding the improvement design is presented in column (7) in tables 5 in the Appendix. 


\subsection{Relevant Anti Fraud Program Design}

The fraud risk assessment process results showed that the organization faces residual fraud risk exposures that must be addressed immediately. The description in the appendix describes the evaluation and discussion with the management in reducing the potential risk to the level of risk appetite. In addition, this study also evaluated and discussed the implementation of anti-fraud program strategies that are appropriate for the organization, both in prevention and detection. The anti-fraud program strategy design was based on the results of the fraud risk assessment and evaluation results of the previous implementation of anti-fraud strategies (internal controls, WBS, codes of ethics and others) and anti-fraud program strategies that have never been implemented at DGT. Fraud triangle theory and rational choice theory are conducted to improve understanding of the characteristics of fraud behavior and how to determine appropriate relevant anti fraud program.

\subsubsection{Preventive Anti Fraud Program Strategy}

a) Build Effective DGT Internal Audit

Good internal audit has an effect on the effectiveness of anti fraud programs (Petraşcu \& Tieanu, 2014). The results of questionnaires and interviews indicated that the effectiveness of internal controls and the role of internal audit function at DGT have not been maximized. A portion of 37\% of the respondents stated that the internal control applied by DGT was less effective and $46 \%$ of respondents believed that the organization did not have an effective internal audit. In addition, the interviewees stated that the organization faced organizational structure problems. One of the problems was that the organizational structure of the internal audit unit was less independent because it was only in echelon IV units (Compliance Testing Section) under Internal Compliance Subdirectorate, Directorate of KITSDA. The weak position of the internal audit unit in the organizational structure was susceptible to interference. With regard to resources, the number of internal audit staff was relatively small at around 19 people (in Compliance Testing Section) without proper internal auditor certification (QIA, CIA and others). This condition of lack of resources was faced by the internal audit in supervising around 40,000 employees in 350 office units. Nevertheless, internal audit's work is assisted by the Internal Compliance Unit in each tax office but is limited to monitors and administration.

In connection with the problems of the internal audit unit organizational structure, the results of the discussion and evaluation of this study concluded that the internal audit unit must be structurally responsible directly to the Director General of Taxes and functionally to the supervisory/commissioner committee to maintain independence in carrying out their duties. It also answered the research of Alfurqan (2017) relating to the need for research to design a good and independent internal audit division structure. IIA (2009) stated that threats to independence and objectivity must be managed at the individual auditor, implementation, functional and organizational level, and the internal auditor's activities must be free from interference, especially within the scope of the audit and reporting tasks. The phenomenon of independence can be explained in the fraud triangle theory that if the internal auditor unit is not independent, it will be an opportunity for senior/top managers to use their influence to interrupt the fraud handling process.

In addition, the effectiveness of the internal audit's role can be increased through increasing human resource capacity by increasing the number of audit staff in accordance with DGT's span of control and increasing their skills. Internal audit implementation must be appropriate for the size of the organization and operations of the organization (Deloitte, 2009). The improved internal audit capacity will have a positive effect on internal audit performance in detecting fraud, such as the ability to use analytical reviews 
(Hillison, Pacini, \& Sinason, 1999). Rational Choice Theory predicts that fraud can be prevented by increasing the probability to detect fraud (Becker, 1974). Historical data for 2017 showed that the implementation of internal audits at DGT has not been able to detect fraud well, detection has been carried out only through the complaints process, WBS, external audit, and others.

b) Code of Ethics And Tone At The Top

DGT has implemented a code of ethics through the rules of 9 obligations and 8 prohibitions for employees, as well as the "Teladan Pimpinan" program which is one of the cultural programs at DGT. In this regard, the results of the questionnaire indicate that $4 \%$ of respondents stated that their superiors/senior management did not encourage or not show ethical behavior. In addition, $25 \%$ of respondents stated that their superiors/senior management did not seem to care or did not respect the behavior of good employees. In fact, $73 \%$ of respondents stated that they knew there were employees who did not like their superiors.

In supporting the successful implementation of the code of ethics, it should be done holistically, starting from the frequency of the socialization of the code of ethics and supervision by the authorized unit. The implementation of a cultural audit also needs to be carried out, in addition to the supervision attached by superiors. The implementation of the "tone at the top" must be aligned with "walk to the talk", with the meaning that the statements, expressions, and sayings that come from the top of management must also be consistent with what is implemented. The code of ethics is the responsibility of all employees and the element of leadership is very important. Fraud triangle theory explains that rationalization is one of the trigger elements of fraud behavior. For example, employees can rationalize their unethical behaviors is acceptable because their superiors behave unethically and not be penalized.

c) Strengthening Human Resource Policies Related To The Preventive Anti Fraud Strategy

One of the human resource policies that support the preventive anti fraud strategy is by giving employees the obligation to take annual leave. DGT has not yet have a regulation that obligates employees to take annual leave, but the results of the questionnaire show that $8 \%$ of respondents stated that the rules for the obligation of annual leave have been applied in their respective offices.

The organization needs to implement an annual leave obligation policy. The implementation of annual leave will allow detection of fraud in terms of the results of work performed by employees who take annual leave by the employee who replace them. One of the red flags related to this is that employees are too protective in their work area. In accordance with rational choice theory, this condition allows employees who commit fraud to consider not committing fraud. This is because there is a possibility that fraud can be detected during annual leave.

d) Know Your Customer

Although DGT has implemented the Know Your Employee program, DGT has never implemented a Know Your Customer program or Know Your Tax Payer. The results of the interviews indicate that the understanding of taxpayers is very important, especially to know the track record and their organizational culture. This is needed to anticipate the potential for kick back, bribery, and gratuities from taxpayers. The opportunity aspect in fraud triangle theory explains why Know Your Tax Customer/Know Your Tax Payer is so important. As an example of an interview, when the first tax auditor comes to submit a Tax Auditing Notification Letter to Taxpayers, the 
opportunity is often used by Taxpayers to provide a banquet of facilities such as luxurious and in-hotel banquets for the purpose of influencing the results of the tax audit. This opportunity gap can be avoided, if the tax auditor knows the taxpayer's organizational track record/culture, either through experience or other historical data so that they can anticipate it first. This program will be more effective when coupled with a customer awareness program, to increase awareness and the possibility of fraud from the customer/tax payer side.

e) Make effective anti fraud procedures.

About $37 \%$ of respondents in the questionnaire said that each business process in the organization did not meet the appropriate internal control. This condition is an evaluation of whether the procedures in business processes have or have not been carried out with proper internal control functions. In rational choice theory, the existence of internal control that effectively detects fraud in every business process procedure will be able to undermine the intention of fraudsters to commit fraud. The decision of a person committing fraud basically requires a cost-benefit analysis. If the fraudster thinks that the expected benefits are insignificant compared to the sanctions and probabilities to be detected, then rational individuals will choose not to commit fraud.

f) Other anti fraud programs.

Some of the other anti-fraud programs that can be done to improve the effectiveness of fraud handling include building a Fraud Risk Awareness, employee background check procedures, proactive investigations and others. Background check procedures minimize getting incoming staff with a high level of criminal risk. Investigation not only functions reactive in detecting fraud, but also has a preventive function. Proactive investigation aims to identify and control the risk of fraud (but not yet identified) or financial irregularities.

\subsubsection{Detective_Anti Fraud Program Strategy}

a) Mystery Shopping

Mystery shopping can be a new anti-fraud program at the DGT. Mystery shopping is a tool for organizations to measure service quality, compliance, ethical codes and organizational culture that has been built. Mystery shopping can be a tool to detect fraudulent behavior in organizations. For example, mystery shopping can be carried out by DGT internal auditors by pretending to be a taxpayer. Posing as taxpayers, internal auditors can ask specific questions relating to employee integrity. Questions can be focused on areas with high fraud risk based on fraud risk assessment, because in high risk areas there is a lack of strong controls. Fraud actors tend to carry out their actions in areas with a low risk of detection, in accordance with rational choice theory.

b) Whistle Blowing System (WBS).

The results of the interview indicate that there were still many aspects that needs to be addressed by management to strengthen WBS policy and practice procedures. Good WBS rules and policies are one of the determinants of the success of handling fraud. The current condition of employees has a tendency to be afraid of delivering fraud through the WBS, mainly due to fears of the confidentiality of the reporter's information, potential retaliation from the reported party and others. In addition, some informants felt a dilemma because even though the application of the WBS had a good impact on the organization, on the other hand it was feared to be regarded as a traitor and had no esprit de corps soul. 
The discussion in this study requires the strengthening of WBS policy and practice procedures. This is consistent with Cordis \& Lambert (2017) research that WBS regulations have an important role in fighting corporate fraud. Expansion and strengthening of protection against reporters must be increased including information security and potential retaliation, not only staff but also non-staff. In the perspective of deontological theory, the disclosure of truth is an obligation and therefore a staff member needs to get information that the WBS reporting is mandatory. In another perspective, the teleology theory explains that whether or not, an action is based on its ultimate goal, so that a false assumption is that the WBS will damage the spirit of de corps, because the truth is the WBS improves the achievement of the ultimate goal. In addition, the procedure for granting rewards to reporters must also be kept confidential to prevent disclosure of information on the identity of the reporter. In addition, there is a great need for a no sanctions policy for misguided or false reporting to ensure that the reporter does not need to worry about something wrong with the report or lack of sufficient evidence.

c) Key Fraud Indicators / Red Flag

Another way to detect fraud is to identify the existence of a red flag or symptoms of fraud. Every concealment of fraud, must be related to the existence of the Red Flag. The application of red flags in organizations can encourage the creation of an effective detection method process. Therefore, building a fraud red flag into an audit plan is very important (Vona, 2008). The results of the questionnaire showed that as many as $57 \%$ of respondents reported information related to personal debt/credit problems, $23 \%$ of respondents reported that there were employees who consumed alcohol, and $39 \%$ of respondents reported that there were employees who had business interests that might conflict with office tasks. The results of the questionnaire are examples of red flags, which although not necessarily lead to fraud behavior, should be a concern of management in managing fraud handling. In fraud triangle theory, one of the reasons why someone commits fraud is the presence of pressure, for example, such as a large personal debt pressure which can lead to criminal activities in order to pay off debt.

\section{CONCLUSION}

The results of this study indicate that there were 20 fraud scenarios identified in the tax audit and extracting potential tax revenues. Fraud risk assessment in this scenario concluded 7 scenarios with high residual fraud risk, 9 scenarios with medium levels and the rest at low levels. This research prioritized the handling of residual fraud risk at high and medium levels so that it can be reduced to the level of organizational risk appetite. Evaluation and discussion was carried out for the design of the appropriate control design for residual fraud risk.

In addition, this study evaluated and discussed anti-fraud strategies that were relevant to the organization, through evaluating anti-fraud program strategies that have been implemented previously and proposed anti-fraud program strategies that have never been implemented. The anti-fraud program strategy design was in the form of preventive strategies and detective strategies. The preventive strategy included to build an effective internal audit, improve the ethical code holistically, tone the top, know your customer, and others. While the detective strategy included mystery shopping, whistleblowing system, key fraud indicator, and others. The success of this anti fraud strategy relies on the awareness and active role of all parties.

This research indicated that there were still many aspects that needs to be addressed by DGT to strengthen fraud handling. The expected implications (research implication) from this research is that the government (DGT) should further enhance 
the anti-fraud program strategy, especially using fraud risk assessment and take the necessary steps as described in this study. DGT must also carry out periodic fraud risk assessments to mitigate the risk of fraud due to changes in the organization's business environment and processes. In addition, risk management policies should be sharper in identifying fraud schemes and aligned in the internal audit planning process.

\section{Research Limitations}

This study was only carried out on two main business processes, namely tax audit and extracting potential tax revenues. This research was limited to the focus of fraud schemes in an internal (management) perspective. This study also only proposed the design of handling controls over residual fraud risk at the medium and high levels. In addition, there was a tendency for some informants to be reluctant or not to disclose all their knowledge related to fraud schemes for reasons of concern, fear, bureaucracy, and others even though they had previously been informed that the identity of the informant was kept confidential.

\section{Suggestion for Further Research}

For further research, the identification process of fraud risk assessment can be carried out in other business processes so that it can illustrate the potential risk of fraud that must be handled by the organization more broadly, especially for taxation public sector agencies. Identification of fraud schemes and fraud scenarios to be seen not only from internal organizational perspectives but also from external perspectives such as taxpayers and related parties. In addition, further research is expected to be able to design audit procedures and anti-fraud programs holistically regarding the risk of fraud.

\section{References}

Alfurqan, R. (2017). Implementation of Business Process Fraud Risk Assessment to Minimize the Fraud Risk Occurance Case Study at PT. TI. APBEC.

Becker, G. S. (1974). Crime and Punishment: An Economic Approach. In University of Chicago and National Bureau of Economic Research. https://doi.org/10.1016/S0002-9610(56)80126-8

Bell, E. O. (2010). Internal Control Checklist: 5 Anti-Fraud Strategies to Deter, Prevent, Detect. Deloitte.

Cordis, A. S., \& Lambert, E. M. (2017). Whistleblower laws and corporate fraud: Evidence from the United States. Accounting Forum, 41(4), 289-299. https://doi.org/10.1016/j.accfor.2017.10.003

Cotton, D. L., Johnigan, S., \& Givarz, L. (2013). Fraud Risk Management Guide. COSO, 1-12.

Cressey, D. R. (1953). Other People's Money. Montclair. NJ: Patterson Smith.

Deloitte. (2009). Sample listing of fraud schemes. Deloitte, 10.

Direktorat Jenderal Pajak. (2016). Laporan Tahunan 2016. Jakarta: Direktorat Jenderal Pajak.

Direktorat Jenderal Pajak. (2017). Laporan Kinerja Direktorat Jendral Pajak. Jakarta: Direktorat Jenderal Pajak.

Ellet, W. (2009). Case Study Handbook. In Harvard Business School Press.

Gao, L., Srivastava, R. P., \& Mock, T. J. (2008). An Evidential Reasoning Approach to Integrating Fraud Schemes into Fraud Risk Assessment under DempsterShafer Theory. (September). 
Ghura, D. (1998). Tax Revenue in Sub Saharan: Effects of Economic Policies and Corruption (No. WP/98/135). Retrieved from https://books.google.co.id/books?id=wzjZHcFjBLoC\&printsec=frontcover\&hl= id\&source=gbs_ge_summary_r\&cad=0\#v=onepage\&q\&f=false

Hillison, W., Pacini, C., \& Sinason, D. (1999). The internal auditor as fraud-buster. Managerial Auditing Journal, 14(7), 351-363. https://doi.org/10.1108/02686909910289849

Hussaini, U. (2018). The effect of fraud risk management, risk culture, and performance of banking sector: A proposed framework. Managerial Finance, 23(3), 1-20. https://doi.org/10.6007/IJARAFMS/v8-i3/4798

Institute of Internal Auditors. (2009). IIA position paper: The role of internal auditing in enterprise-wide risk management. Institute of Internal Auditors (IIA), (January), 1-8. Retrieved from https://na.theiia.org/standards-guidance/Public Documents/PP The Role of Internal Auditing in Enterprise Risk Management.pdf

Keuangan Kementerian. (2013). Peraturan Menteri Keuangan Nomor 17/PMK.03/2013. Jakarta: Kementerian Keuangan.

KPMG Forensics. (2014). Fraud Risk Management: Developing a strategy for prevention, detection, and response. KMPG Cutting through Complexity, (May), 1-57. https://doi.org/10.1002/9781119203889.ch8

Nicke, L. (2003). Black Law dictionary 8th. Black Law Dictionary.

Padgett, S. (2015). About the Association of Certified Fraud Examiners and the Report to the Nations on Occupational Fraud and Abuse. Profiling the Fraudster, 239242. https://doi.org/10.1002/9781118929773.oth1

Petraşcu, D., \& Tieanu, A. (2014). The Role of Internal Audit in Fraud Prevention and Detection. Procedia Economics and Finance, 16(May), 489-497. https://doi.org/10.1016/s2212-5671(14)00829-6

Rizal, Y. (2011). Lessons from Indonesian Tax Administration Reform Phase 1 (20012008): Does Good Governance Matter? Limits of Good Governance In Developing Countries, 363-412.

Rose, A. M., \& Rose, J. M. (2003). The effects of fraud risk assessments and a risk analysis decision aid on auditors' evaluation of evidence and judgment. Accounting Forum, 27, 312-338. https://doi.org/10.1111/1467-6303.00108

Stake, R. E. (2000). Handbook of Qualitative Research. 2nd Edition (E. N. Denzin and Y. Lincoln, Ed.). Thousand Oaks, CA: Sage.

Vona, L. W. (2008). Fraud Risk Assessment: Building a Fraud Audit Program. https://doi.org/x148

Wasistha, G., Yuniasih, R., \& Shauki, E. R. (2018). Panduan Penulisan Thesis Magister Akuntansi. Jakarta: Universitas Indonesia.

Widoretno, A. A. (2016). Analisis Efektivitas Penerapan Strategi Anti-Fraud Dalam Upaya Mewujudkan Good Corporate Governance: Studi Kasus Pada PT. XYZ. 


\section{Appendix}

Table 5 Control Effectiveness dan Design Improvement in Tax Audit

\begin{tabular}{|c|c|c|c|c|c|c|}
\hline No. & $\begin{array}{l}\text { Fraud } \\
\text { Schemes }\end{array}$ & Fraud Scenario & $\begin{array}{l}\text { Existing Anti } \\
\text { Fraud Control }\end{array}$ & $\begin{array}{c}\text { Control } \\
\text { Effectivesness }\end{array}$ & $\begin{array}{c}\text { Residual } \\
\text { Risk } \\
\text { Vulnerabi } \\
\text { lity Level }\end{array}$ & Design Improvement \\
\hline (1) & (2) & (3) & (4) & (5) & (6) & (7) \\
\hline 1 & $\begin{array}{l}\text { Underbilling } \\
\text { and Kick } \\
\text { Back } \\
\text { Schemes }\end{array}$ & $\begin{array}{l}\text { Officers get compensation from taxpayers for } \\
\text { reducing the amount of tax that should be paid. } \\
\text { The scenario is through correction of income, } \\
\text { expenses and not imposing fines. }\end{array}$ & $\begin{array}{l}\text { Review by } \\
\text { Supervisor }\end{array}$ & $\begin{array}{l}\text { The team review } \\
\text { will fail if there is } \\
\text { collusion in the } \\
\text { team }\end{array}$ & High & $\begin{array}{l}\text { 1. Apply peer review. } \\
\text { 2. Immediate investigation related to } \\
\text { unusual changes in historical data } \\
\text { on tax payments } \\
\text { 3. Strengthening WBS } \\
\text { 4. Application of the Red Flag/Key } \\
\text { Fraud Indicator }\end{array}$ \\
\hline 2 & $\begin{array}{l}\text { Mark Up } \\
\text { Billing } \\
\text { Schemes }\end{array}$ & $\begin{array}{l}\text { The officer made a mark-up on the amount of the } \\
\text { tax payable that made the Taxpayers shock so } \\
\text { that it triggered negotiations on reducing the tax } \\
\text { payablex }\end{array}$ & $\begin{array}{l}\text { Minutes of Tax } \\
\text { Audit Result } \\
\text { Procedure (BA } \\
\text { PHP) }\end{array}$ & $\begin{array}{l}\text { BA PHP procedure } \\
\text { is not maximal } \\
\text { because } \\
\text { negotiation is done } \\
\text { before BA PHP. } \\
\text { The Integrity Pact } \\
\text { impressed } \\
\text { formality }\end{array}$ & Medium & $\begin{array}{l}\text { 1. Arrangement of distribution of } \\
\text { assignments to team members } \\
\text { must be evenly distributed, } \\
\text { avoiding distribution per member } \\
\text { per Taxpayer } \\
\text { 2. Peer review } \\
\text { 3. Strengthening WBS }\end{array}$ \\
\hline 3 & $\begin{array}{l}\text { Illegal } \\
\text { Gratuities }\end{array}$ & $\begin{array}{l}\text { Officers receive compensation from taxpayers } \\
\text { because official action is taken (without any } \\
\text { element of violation), usually when examining } \\
\text { tax refunds. }\end{array}$ & $\begin{array}{l}\text { Gratification } \\
\text { Control Unit } \\
\text { (UPG) }\end{array}$ & $\begin{array}{l}\text { UPG is only } \\
\text { effective if there } \\
\text { are reports }\end{array}$ & Medium & $\begin{array}{l}\text { 1. Application of a surprise cash } \\
\text { count, in the workspace. } \\
\text { 2. Application of the Red Flag } \\
\text { 3. Strengthening WBS }\end{array}$ \\
\hline 4 & \begin{tabular}{|l|} 
Expense \\
reimburseme \\
nt schemes
\end{tabular} & $\begin{array}{l}\text { Officers falsify information in Official Travel } \\
\text { Letters to Taxpayers for the purposes of } \\
\text { reimbursing travel money }\end{array}$ & $\begin{array}{l}\text { Review by } \\
\text { Management }\end{array}$ & Less effective & Medium & $\begin{array}{l}\text { 1. Confirmation sampling procedure } \\
\text { to Taxpayers, consistently. } \\
\text { 2. Application of a surprise cash } \\
\text { count, to officials who carry out } \\
\text { authorizations }\end{array}$ \\
\hline 5 & \begin{tabular}{l|} 
Management \\
Override - \\
Political \\
issue
\end{tabular} & $\begin{array}{l}\text { The Head of the Tax Office intervenes on the } \\
\text { draft results of the tax audit, because there is a } \\
\text { conflict of interest issue with Taxpayers, politics } \\
\text { and others. }\end{array}$ & - & - & High & $\begin{array}{l}\text { 1. The replacement of team members } \\
\text { by the head of office must be } \\
\text { reported to the Regional Office. } \\
\text { 2. Peer review \& Strengthening } \\
\text { WBS \& employee mutation } \\
\text { policies }\end{array}$ \\
\hline 6 & $\begin{array}{l}\text { Management } \\
\text { Override }\end{array}$ & $\begin{array}{l}\text { Officers intentionally do not perform calculations } \\
\text { according to the rules of the method and audit } \\
\text { techniques in order to ease the work, so that it } \\
\text { affects the tax calculation. }\end{array}$ & $\begin{array}{l}\text { Approval of } \\
\text { the Head of } \\
\text { Office for tax } \\
\text { assessments }\end{array}$ & Less effective & Low & - \\
\hline
\end{tabular}


AFEBI Accounting Review (AAR)

Vol.04 No.02, December 2019

\begin{tabular}{|c|c|c|c|c|c|c|}
\hline No. & $\begin{array}{c}\text { Fraud } \\
\text { Schemes }\end{array}$ & Fraud Scenario & $\begin{array}{l}\text { Existing Anti } \\
\text { Fraud Control }\end{array}$ & $\begin{array}{c}\text { Control } \\
\text { Effectivesness }\end{array}$ & \begin{tabular}{|c|} 
Residual \\
Risk \\
Vulnerabi \\
lity Level \\
\end{tabular} & Design Improvement \\
\hline (1) & (2) & (3) & (4) & (5) & $\begin{array}{l}\text { (6) } \\
\end{array}$ & (7) \\
\hline 7 & Collusion & $\begin{array}{l}\text { Management "organize" the proposal/assignment } \\
\text { of tax audits (SP2) of Taxpayers to certain teams } \\
\text { with the intention of obtaining personal / group } \\
\text { benefits. }\end{array}$ & $\begin{array}{l}\text { The proposed } \\
\text { team } \\
\text { assignment } \\
\text { procedure } \\
\text { KPI settings } \\
\text { per individual }\end{array}$ & $\begin{array}{l}\text { Less effective. } \\
\text { Head of Office has } \\
\text { the authority to } \\
\text { determine the team }\end{array}$ & High & $\begin{array}{l}\text { 1. Implementation of the objection } \\
\text { procedure for the appointment of } \\
\text { the team, addressed to the DGT } \\
\text { Regional Office. } \\
\text { 2. Strengthening WBS }\end{array}$ \\
\hline 8 & $\begin{array}{l}\text { Conflict of } \\
\text { Interest }\end{array}$ & $\begin{array}{l}\text { Officers are secretly involved in consulting firms } \\
\text { that serve tax consultations, so that they are } \\
\text { contrary to their duties }\end{array}$ & Code of Ethics & Less Effective & Medium & $\begin{array}{l}\text { 1. Strengthening WBS. } \\
\text { 2. Strengthening code of ethics }\end{array}$ \\
\hline 9 & $\begin{array}{l}\text { Management } \\
\text { Override and } \\
\text { Conflict of } \\
\text { Interest }\end{array}$ & $\begin{array}{l}\text { The team supervisor intentionally makes the } \\
\text { audit plan/audit program not according to the } \\
\text { rules so that team members are difficult to detect } \\
\text { errors. This is because there is an internal } \\
\text { conflict of interest of the team regarding } \\
\text { Taxpayers. }\end{array}$ & $\begin{array}{l}\text { Approval of } \\
\text { Head of Office } \\
\text { in Audit Plan }\end{array}$ & Effective enough & Low & - \\
\hline 10 & $\begin{array}{l}\text { Collusion/fal } \\
\text { se statement }\end{array}$ & $\begin{array}{l}\text { Collusion of officers with Taxpayers when } \\
\text { giving assignment of tax audits (SP2)to } \\
\text { Taxpayers in the form of providing taxpayer } \\
\text { information that is conditioned with the aim of } \\
\text { producing "sumir" tax assessment letter }\end{array}$ & $\begin{array}{l}\text { Procedure for } \\
\text { giving SP2 by } \\
\text { a minimum of } \\
2 \text { people }\end{array}$ & $\begin{array}{l}\text { Less Effective, if } \\
\text { there is collusion }\end{array}$ & Low & - \\
\hline \begin{tabular}{|l|}
11 \\
\end{tabular} & \begin{tabular}{|l|} 
Conflict of \\
Interest/Illeg \\
al Gratuities
\end{tabular} & $\begin{array}{l}\text { Officers request facilities for taxpayers such as } \\
\text { providing hotels, transportation, food, } \\
\text { entertainment and more. }\end{array}$ & $\begin{array}{l}\text { Integrity Pact } \\
\text { Accompanime } \\
\text { nt regulations }\end{array}$ & Less Effective & High & $\begin{array}{l}\text { 1. Application of procedures for } \\
\text { providing accommodation only by } \\
\text { the office (ticket, hotel,etc). } \\
\text { 2. Strengthening WBS \& } \\
\text { Strengthening the internalization } \\
\text { of the code of ethics }\end{array}$ \\
\hline 12 & $\begin{array}{l}\text { Conflict of } \\
\text { Interest }\end{array}$ & $\begin{array}{l}\text { Social feelings and compassion for the taxpayer's } \\
\text { financial conditions make the officer calculate } \\
\text { taxes based on the taxpayer's ability to pay. }\end{array}$ & $\begin{array}{l}\text { Riview by } \\
\text { Supervisor }\end{array}$ & Less Effective & High & $\begin{array}{l}\text { 1. Implement Peer review. } \\
\text { 2. Strengthening the internalization } \\
\text { of the code of ethics }\end{array}$ \\
\hline 13 & $\begin{array}{l}\text { Illegal } \\
\text { Gratuities }\end{array}$ & $\begin{array}{l}\text { Officers avoid detection of gratuities through } \\
\text { hard-to-track instruments such as insurance } \\
\text { policies, investments, and placement of family } \\
\text { members as employees of taxpayers by obtaining } \\
\text { large salaries. }\end{array}$ & - & - & High & $\begin{array}{l}\text { 1. Strengthening the IT system for } \\
\text { exchanging financial information } \\
\text { and data with third parties. } \\
\text { 2. Strengthening WBS }\end{array}$ \\
\hline
\end{tabular}


Implementation of Fraud Risk Assessment To Mitigate The Fraud Risk in Tax Audit Process

\begin{tabular}{|c|c|c|c|c|c|c|}
\hline No. & $\begin{array}{l}\text { Fraud } \\
\text { Schemes }\end{array}$ & Fraud Scenario & $\begin{array}{l}\text { Existing Anti } \\
\text { Fraud Control }\end{array}$ & $\begin{array}{c}\text { Control } \\
\text { Effectivesness }\end{array}$ & $\begin{array}{l}\text { Residual } \\
\text { Risk } \\
\text { Vulnerabi } \\
\text { lity Level } \\
\end{array}$ & Design Improvement \\
\hline (1) & (2) & (3) & (4) & (5) & (6) & (7) \\
\hline 14 & $\begin{array}{l}\text { Kick back - } \\
\text { advance } \\
\text { communicati } \\
\text { on }\end{array}$ & $\begin{array}{l}\text { The management person leaks information to the } \\
\text { Taxpayer regarding information on the tax audit } \\
\text { proposal letter to the Taxpayer before the } \\
\text { issuance of assignment of tax audits (SP2). }\end{array}$ & - & - & Low & - \\
\hline 15 & $\begin{array}{l}\text { Conflict of } \\
\text { Interest - } \\
\text { Shifting } \\
\text { playing field }\end{array}$ & $\begin{array}{l}\text { The officer directed to conduct an appeal process } \\
\text { due to the strict supervision of the DGT, and } \\
\text { promised to settle the case because there was } \\
\text { already tax court level communication }\end{array}$ & - & - & Medium & $\begin{array}{l}\text { 1. Application of the Red Flag/Key } \\
\text { Fraud Indicator. } \\
\text { 2. Strengthening employee mutation } \\
\text { and job rotation systems }\end{array}$ \\
\hline 16 & $\begin{array}{l}\text { Conflict of } \\
\text { Interest }\end{array}$ & $\begin{array}{l}\text { Officers direct Taxpayers to use certain tax } \\
\text { consultants for certain cases, in order to get } \\
\text { compensation from consultants }\end{array}$ & - & - & Medium & $\begin{array}{l}\text { 1. Application of the Red Flag } \\
\text { Key Fraud Indicator } \\
\text { 2. Strengthening WBS } \\
\text { 3. Strengthening the internalization } \\
\text { of the ethics }\end{array}$ \\
\hline 17 & $\begin{array}{l}\text { Economic } \\
\text { Extortion }\end{array}$ & $\begin{array}{l}\text { Officers request money to the former taxpayer } \\
\text { who had been audited previously for certain } \\
\text { reasons. }\end{array}$ & Code of Ethics & Less Effective & Medium & 1. strengthening WBS \\
\hline 18 & $\begin{array}{l}\text { Theft of } \\
\text { Cash } \\
\text { Receipts - } \\
\text { Skimming/ } \\
\text { Lapping }\end{array}$ & $\begin{array}{l}\text { Officers postpone/do not deposit money from the } \\
\text { Taxpayer related to arranging tax payments. } \\
\text { Taxpayers sometimes deposit money with } \\
\text { officers because they trust officers. }\end{array}$ & Code of Ethics & Less Effective & Low & $\begin{array}{l}\text { 1. Strengthening WBS, } \\
\text { 2. Strengthening the internalization } \\
\text { of the code of ethics }\end{array}$ \\
\hline 19 & $\begin{array}{l}\text { Conflict of } \\
\text { Interest }\end{array}$ & $\begin{array}{l}\text { The closeness of relations with taxpayers can } \\
\text { create a conflict of interest of officers in the task } \\
\text { of auditing taxpayers. }\end{array}$ & Staff mutation & Effective enough & Medium & $\begin{array}{l}\text { 1. Periodic rotation of taxpayer } \\
\text { assignments to officers. }\end{array}$ \\
\hline 20 & $\begin{array}{l}\text { Kick Back } \\
\text { Schemes }\end{array}$ & $\begin{array}{l}\text { The officer sells taxpayer risk analysis data that } \\
\text { is not continued to the proposed special audit } \\
\text { stage (proposal of tax audit). }\end{array}$ & - & - & Medium & $\begin{array}{l}\text { 1. Strengthening WBS } \\
\text { 2. Strengthening the intermalization } \\
\text { of the code of ethics }\end{array}$ \\
\hline
\end{tabular}

Notes: : 1. Strengthening the WBS, through: no sanctions for misguided or false reporting, full anonymous reporting, reporting protection.

2. The application of the Red Flag/Key Fraud Indicator, will improve the Internal Audit Function(IAF) by considering the red flag in the internal audit plan 